\title{
Šárka in the Eyes of Czech Composers, Attractive as Well as Ill-Favoured
}

\author{
Jiří Zahrádka
}

With the start of the Czech society's efforts for emancipation in the second half of the $19^{\text {th }}$ century a new field for the right dramaturgy and topics of Czech operas came into being, together with the birth of Czech national opera. Besides comic operas, e.g. operas with countryside themes, there appear motives from Czech history (rather idealized) and also, under the influence of German opera, motives from Czech mythology. One of the important motives which appealed to Czech composers was the story of the "females' war".

Stories about warlike women called Amazons were known even in antiquity and later on they emerged in the myths of some European nations. The Czech legend about the fight between women and men, i.e. about the so-called "females' war", is first portrayed in Cosmas's chronicle. The Latin Chronicle of the Czechs was written in the second decade of the $12^{\text {th }}$ century. A brief story of the "females' war" is divided into three parts. The first depicts an Amazonian way of men's behavior and women's dressing, while the second describes how the women's castle was built and explains its name, "Děvín". The legend of the "females' war" is thus a typical etymological one; the etymology of the castle Děvin-the women's castle-is usual even in the Middle Ages (e.g. Magdeburg). Hence it is a medieval "mobile" motive of the women's city. The third part of Cosmas's storytelling portrays a game of young men and women not as a bloody struggle but as an ending with a conciliation and feast. Cosmas explicitly uses the expression "ludus", i.e. a game. The legend presents a poetic picture of Slavic festivities in nature, most importantly the Pentecostal ones, when young men and women were involved in some ritual promiscuity.

However, in the later versed so-called chronicle of Dalimil from the beginning of the $14^{\text {th }}$ century the legend is portrayed quite differently. Although Dalimil draws on Cosmas's chronicle, the "females' war" as an innocent game of females and males is here changed into a bloody fight and real war. Dalimil developed his interest in depicting fights, scuffles, weapons, and love stories such as that of Ctirad and Šárka. Unlike Cosmas Dalimil inserted a number of names into the legend: the Amazons Vlasta, Mlada, Svatava and above all Šárka. Mr. Karbusický maintains that the origin of the name Šárka can be seen in the etymological personification of the general expression "šárka" used for uneven 
fields, meadows and gulches since Šárka is to wait for Ctirad in a valley which Dalimil describes with the words "even today the spot is called Śárka" ${ }^{1}$. Dalimil's fabulated story is closest to a mobile motive from the German epics mentioned in the Edda. However, it can hardly be determined where Dalimil came across the valkyrie epic poetry.

Subsequent versions by the chronicler Pribík Pulkava from Radenín from the second half of the $14^{\text {th }}$ century, by Aeneás Sylvius Piccolimini (the later pope Pius II) from the $15^{\text {th }}$ century and by Racek Doubravský from Doubravka from the $16^{\text {th }}$ century drew on Dalimil's version of the story. The version by the chronicler Václav Hájek from Libočany from the first half of the $16^{\text {th }}$ century also basically copies Dalimil's story which is however slightly extended. In Hájek's terms the "females' war" took place as follows:

After the princess Libuše's death her virgin maids led by Vlasta lost their respectability with men, and they even seemed to lose the virgin right to choose their husbands themselves, as was the habit when the princess was still alive. Libuše set an example as she chose Přemysl Oráč to be her husband. After an agreement with the women Vlasta let Přemysl know that he should marry her. It was obvious from Přemysl's consent to marry her because he liked her that men wanted to take over the right to choose their wives in the future, which made the women and above all Vlasta furious, and so they declared a war on men. The women built the castle called Děvín opposite Vyšehrad, Přemysl's seat, on the other bank of the Vltava and elected Vlasta their leader. They attracted many women and maids who abandoned their families. Vlasta gave them a sip of a magic drink which made them hate all men and they joyfully fought with a sword against them or tricked them. The brave combatant Ctirad became a target of one of the tricks. In the valley where Ctirad was to ride with his suite the women set a trap-the beautiful Amazon Šárka was handcuffed by the road and left there with a bottle of mead and a hunting horn. Ctirad, captivated by her lamentation came to release her and asked what happened to her. Šárka answered that she had gone hunting with her father, got lost and had been seized by Vlasta's Amazons who wanted to take her to Děvín. But when they heard Ctirad's suite coming, they scattered. Then Šárka offered Ctirad and his whole suite the mead, and when the men were drugged by the sweet drink Šrka asked Ctirad to sound her horn. That was the sign for the Amazons hidden in a forest who rushed in, captured poor Ctirad and murdered the rest of the surprised men. Ctirad was dragged off to Děvín and on the same day they dragged him to the Vltava bank opposite Vyšehrad, interweaved him into a wheel and broke his legs and arms. The men led by Přemysl finally decided to end the women's fury and attacked Děvín. Vlasta fought bravely at the front but when she lost the battle and was killed, the other girls realized that many of them had already died on the battlefield and they wanted to surrender and return humbly to their husbands. However, the men were not merciful, killed them all, sacked Děvín and burnt it down. That was the end of the "females' war".

1 The oldest Czech versed so-called chronicle of Dalimil (Prague, 1958), p. 37. The original Czech is "i dnes tomu miestu Šárka dějú". Since official translations of the quotations given here are not available, all translations are by the translator of this paper. 
Václav Hájek from Libočany leaves out the final part about the infamous end of the traitor Śárka. According to Dalimil Šárka and her sister Darka were captured after the defeat by Ctirad's son and both were buried alive. Šárka's suicide does not appear in Czech chronicles at all and was made up by the artist Julius Zeyer-in his poem Ctirad Šárka petrifies voluntarily and in the libretto she stabs herself. In Anežka Schulzová's libretto she jumps from a rock.

In the $18^{\text {th }}$ and $19^{\text {th }}$ centuries the "females' war" became a popular theme of theatre plays such as Václav Thám's Wlasta a Šárka neb Dívč́ boj u Prahy [Wlasta and Šárka or the Females' War near Prague] (1785-1799), and was also elaborated by literary means, e.g. Prokop Šedivý - České Amazonky aneb Dívčí boj v Čechách, pod správou rekyně Vlasty [The Czech Amazons' or Females' War in Bohemia Conducted by the Heroine Vlasta] (1792). The list of literary and dramatic stories about the legend is found in Hermenegild Jireček’s work Skazka o dívči válce v Čechách z roku 1905 [The Story about the Females' War from 1905]. In the Czech territories there are three librettos about the "females' war" from the pen of Julius Zeyer, Karel Pippich and Anežka Schulzová. I would like to deal with the text by Julius Zeyer, which circulated the most among Czech composers.

Zeyer's letter to Janáček dating 17 November 1887 discloses that the music drama Š́rka was urged by Antonín Dvořák: "He asked me via Prof. Sládek to write him a libretto. I gladly fulfilled his wish." ${ }^{2}$ When Dvoŕák asked Zeyer for the libretto is not clear; however, on 20 February 1878 a memo was published in Hudební a divadelní věstník [Music and Theatre Bulletin] stating that "Antonín Dvořák is writing a new opera Šárka". This note would be the answer to the unclear assignation of the libretto of Śárka, were it not apparent that Śárka could not have been composed before the poem Ctirad from the turn of 1878 and 1879. Zeyer lifted whole passages word for word from the poem in his libretto. Śárka is evidently a reduced and altered version of the poem Ctirad and it is hardly believable that Ctirad originated in an extension of Šárka. Using this topic in a poem was also original. Zeyer describes the instigation in a letter to Jan Voborník: "Once I went for a walk with Vrchlický and we talked about Šárka. We concurred that we would both write Šárka, we would not talk about it any more, would not disclose anything about the conception and we would surprise each other with the completed work. So it happened. Vrchlický wrote Śárka and I wrote Ctirad [...]"3 Zeyer was working on Ctirad from December 1878 until the beginning of January 1879 and straightaway in January the poem was published in the magazine Lumír. Zeyer is likely to have worked on Śárka after he finished Ctirad, i.e. after January 1879. The article in Music and Theatre Bulletin from 20 February 1878, which announced Dvořák's composition of Šárka nearly a year before the completion of Ctirad, remains almost inexplicable. However, in the article it was J. O. V. (Veselý), librettist of Dvoŕák's opera The Cunning Peasant, and not Zeyer, who was named the author of the libretto. What throws light on the creation of the libretto is a note from August 1880 in the magazine Dalibor that Dvorák would compose a new opera

2 The letter is deposited in the Janáček Archive of the Moravian Museum in Brno, call number A 3.376.

3 Jan Voborník, Julius Zeyer (Prague, 1919), p. 81. 
based on the libretto by Julius Zeyer and Josef Sládek. The same entry also appeared in a diary of the librettist Marie Červinková-Riegrová in January 1881. The libretto might then have originated sometime between January 1879 and August 1880. Nevertheless, Dvořák never started working on Šárka and not long after he had decided to compose the opera Dimitrij he returned the libretto to Zeyer. Bedřich Smetana, to whom Śárka was also offered, obviously refused it as well. We find evidence in a letter by Jaroslav Vrchlický to Josef Srb-Debrnov from 10 June 1882, when he was answering Debrnov's request for composing a libretto for Smetana:

Dear Sir! In response to your respectable letter from 30 June I feel honored to answer that the libretto of "Vlasta" exists and the author is Dr. Pippich and the libretto of "Šárka" comes from the pen of Julius Zeyer. Just a modest note-if B. Smetana did not find either the libretto by Mr. Pippich, who is a music expert, or the one by Mr. Zeyer, who is a reputable poet, suitable, mine could hardly be pardoned in his eyes and I would not want to be in the same situation as Mr. Zeyer, whose libretto wandered from Annas to Caiaphas for two whole years without the famous composer writing a single response or word of appreciation for such ungrateful work. Do not think ill of me if I do not seem to be trusting in a similar situation and tell you honestly what is on my mind. ${ }^{4}$

Eliška Krásnohorská also wonders in a letter to Bedřich Smetana from 23 February 1882 why he did not choose any of the librettos. She sheds light in her memoirs on the reasons why Smetana did not want to set the libretto to music:

Once when he returned, he laid a parcel in front of me. "I pray you not to tell anyone I showed you this. They do not want you to know about it. They offer me librettos again, by two poets at a time and I would like you to read them." When I unpacked the manuscripts, I rejoiced since they both contained Old Czech myths, both joined "Libuše" with their topics, both could help the master to fulfil his dearest music wishes. It was "Śárka” from the pen of Julius Zeyer and "Vlasta" - yes, actually Vlasta, written by another author. I read them on the same day and he soon came to pick them up and wanted my opinion too. Both were clearly praiseworthy and I recommended them to him whole-heartedly, for many reasons. However, he lost no time to counteract with his opposing reasons. He objected to Šárka almost nervously; he objected mainly because Libuše, the stunning, noble half-goddess, which he imagined in his "Libuše" as a vital and radiant ideal of a woman, is shown

4 Otakar Šourek, “Dívčí boj” v české opeře [The "Females' War” in Czech Opera], Listy Hudební Matice [Hudební Matice News], 5 (1926), No. 3, p. 95. Karel Krejčí (ed.), Ze vzpomínek Elišky Krásnohorské [From the Memoirs of Eliška Krásnohorská], (Prague, 1950), p. 131. 
here as a "posthumous spook", with which he never wants to spoil his graceful idea of our famous priestess-prophetess $[\ldots]^{5}$

Zeyer must have been somewhat frustrated by this and when he was addressed by the young composer Janáček, who furthermore had already composed an opera based on a heavily distorted text with a testimonial from Antonín Dvořák, he unsurprisingly and fiercely refused to grant permission. Interestingly enough, Dvořák started to take interest in the libretto again in February 1889, as proved by a letter by J. V. Sládek to Zeyer dated 15 April 1889:

I met Dvořák yesterday and we had a long chat. He pleads you to allow him to compose Śarka and not to give her to anyone else. He spoke frankly. When you gave him the text years ago, he was still immature! Now he feels strong enough, he is brave enough for something as big as this and he also understands it. He is totally fascinated, and once he starts working he will complete it soon since the text itself dictates the music. He depicted individual scenes and talked like I have never heard him talking before. He pleaded me to write to you immediately, which I am doing now $[\ldots]^{6}$

This seems inexplicable from Dvořák's perspective. Instead of trying to change Zeyer's viewpoint of Janáček's request and help the already-composed opera of his friend to see the light of day, he assured the poet that he would compose Šárka himself. However, not even after this letter had been sent did Dvořák compose Šárka, and he never returned to it. Dvořák's behavior remains inexplicable; however, Zeyer's motives are clarified to a large extent by the recently-found correspondence of the editor of the magazine Dalibor J. V. Zelený with Julius Zeyer from November 1887:

Kindly read the attached letter, which I have just received, and advise me what to do. I am really sorry now that I have written and printed "Šárka". I do not have the slightest idea who this Janáček is and thus I pray you tell me whether he is a man to be taken seriously. The text does not matter, it must be absolute drivel if it circulated among our composers and no one wanted it; and the texts used for their compositions surely seem to originate somewhere in Karlov. I am only afraid of becoming ridiculous when I get involved with Mr. Janáček. Il ne manque rien que cela à mon infortune.

Bendl once told me that he would set "Šárka" to music; it has been a long time and I forgot about it as well as he did. I've just remembered it and I plead you to show him the letter by Mr. J. If he learnt anything about the situation, he could

5 Ibid., p. 131.

6 Otakar Šourek, Život a dílo Antonína Dvořáka [The Life and Work of Antonín Dvořák], Vol. II 1878-1890 (Prague, 1928), p. 12. 
think I was looking for the gentleman [?]. He knows "Šárka" only from "Česká Thalie”, where it was published, (unfortunately!) I didn't know at that time what this $\check{C}$. Th. turned out to be.

I am sorry once more for bothering you and ask you for a swift reply so that I can answer the gentleman and end such an unpleasant affair. I believe that should he have asked first, I would have refused it and he could have saved his effort, my uneasy moments, and your reading of this letter. ${ }^{7}$

Zelený's reply came in no time. He sharply opposed his "anti-Smetana" adversary in a letter written right away the next day:

L. Janáček, known in music environs as a Brno opponent of Prague music and namely of Smetana's modern trend, seems to be a man of ability and great diligence, but he is hot-headed for sure, although he is no longer a child but a grown-up man. Dvořák has seen his opera as well as Bendl, who, laughing, described how approximately 3 weeks ago Janáček, a sky-high anti-Wagnerian, composed an opera that was hyper-Wagnerian in some respects and whose parts were thus mostly impossible to sing. Besides, he also noted that his technique shows enormous weaknesses and his inventiveness is sometimes quite pretty but on the whole rather shabby. Bendl got hold of the outline only for a short while at Dvořák's, whose judgment -unknown to me-is probably substantially more positive. Janáček is Dvořák's unilateral propagator in Brno and Dvořák praised him highly as early as last year for very primitive choruses which Janáček donated him [3 male choruses, JW IV/19]. On the other hand, Bendl is of a diametrically opposite opinion! I would assume myself that your literary lost could not have been big if Janáček's opera had not come into the world. Besides, I regard his behavior, i.e. the first outline of the whole opera-to say nothing of royalties-so disrespectable that any similar misuse of someone's possession should not be supported. I favor younger composers for sure and I wish them poetic librettos first-but in my opinion this case calls for an exemplary intervention. However, NB-I had brisk disputes with J. [the dispute concerns Janáček's article "Bedřich Smetana on Musical Forms" published on 15 November 1886 in Hudební listy]-I am perhaps not objective!Let me also include a comment about your note on the libretto itself. You are right, our composers carried out a direct assassination of our senses; but Šárka cannot be set to music either by the non-dramatic Dvořák or Bendl, who, speaking in total confidence, lacks sincerity in his work and enough strength. I still do not know whether in the course of time Fibich could work on it [Fibich indeed composed the opera Šárka in 1896 but used a libretto by Anežka Schulzová]; he is already working on something with Hostinský (votre horreur - mon faible) [this is Fibich's

7 The letter is deposited in the Památník národního písemnictví v Praze [Museum of Czech Literature in Prague] (hereafter MCL), the Václav Vladimír Zelený Fund. 
opera The Bride of Messina based on Hostinský's libretto]. Šárka's peculiar characteristics could only have been accommodated, of all our authors, by Smetana, if he had not been so restrained by Eliška; her action is very brief with its lapidary features. Do not take it as me reproaching a mistake. To make you believe in my sincerity I admit that I did not consider some trifle in the introductory verses worth your standard. A brief action is not a mistake for a great composer, who understands the full potential of lyrics and features strong broad stresses in his accent such as Wagner, for whom Šárka seems to be written, although Smetana could also have done justice to her musical needs. Thus I myself did not advise Bendl to take charge of Śárka-it would have been spoiled. I guess a poet like you is probably able to hold on with his work.

I hurried up with my answer to save you from thinking in vain about the unpleasant situation. ${ }^{8}$

The above-presented letter reveals not only a great deal about Zelenýs view of Janáček but it is also valuable evidence of what the Prague artistic and intellectual society thought about the young Moravian composer. Usurprisingly Zeyer decided not to fulfil his request, which is apparent in Zeyer's answer to Zelený from 20 November 1887:

Thank you very much for your information on the bizarre Mr. Janáček. I call him bizarre to avoid labeling him with a different, less picturesque word. I refused his request in a considerate way and politely but I got a second letter, which seems to collide with my reply. It was frankly insolent. At least I thought so and I responded a little bit less considerately. Now I pity him; hopefully he is only as naïve as our dull "Dante - Šubert" in the poem in "Lumír". What an ideal period we live in! Even a Merry Andrew pretends he is a poet. ${ }^{9}$

Even though it is apparent that Zelený's negative report on Janáček was of fundamental importance for Zeyer's decision, it could also be influenced by the poet's injured vanity since his libretto was de facto refused by three prominent Czech composers: Bedřich Smetana, Antonín Dvořák and Karel Bendl. Janáček still worked on Šárka but it was not staged until 1925.

More than a quarter of a century earlier, in 1897, Zdeněk Fibich's opera Šárka was performed for the first time. The story of Šárka and Ctirad as written by Anežka Schulzová is very different from Zeyer's version since Śárka reveals her betrayal to Ctirad and he himself sounds her horn to call the women whom he wanted to fight with. Ctirad succumbs but Śárka saves him and declares him her fiancé. Ctirad is found guilty by the women and he is to be interwoven into the wheel. To save him Śárka resorts to a betrayal and asks the men for help. They liberate Ctirad at the last moment but Śarka being remorseful

8 The letter is deposited in the same location.

9 The letter is deposited in the same location. 
jumps from the rock. After the success of Fibich's Šárka Antonín Dvořák began to take interest in Pippich's libretto Vlasty skon [Vlasta's Demise]. He reverted to the libretto in 1901 once more but as soon as he found out that the text was being adapted by Otakar Ostrčil he gave up on the idea of setting it to music. The first performance of Ostrčil's opera Vlasta's Demise was held in 1904.

Although Janáček's Śárka had its premiere delayed until 1925, it is, thanks to its creation in 1887-8, the first Czech opera on the "females' war".

Translated by Ivana Kočová

\section{Šárka, eine für tschechische Komponisten anziehende und abstoßende Heldin}

\section{Zusammenfassung}

Das Thema des Mädchenkrieges erscheint in der tschechischen Literatur zum ersten Mal in der Chronica Bohemorum des Cosmas von Prag, wo sie jedoch lediglich als ein ritueller Wettstreit zwischen den jungen Männern und den Mädchen geschildert wird. In der am Anfang des 14. Jahrhunderts auf Tschechisch in Versen geschriebenen Chronik des sogenannten Dalimil wird die Sage bereits als ein Krieg der Frauen mit einer ausgearbeiteten Handlung und konkreten Personennamen beschrieben. Weitere Versionen der Sage stammen vom Chronisten Přibík Pulkava von Radenín (Pulkawa von Radenin) aus der zweiten Hälfte des 14. Jahrhunderts, von Aeneas Sylvius Piccolomini (dem späteren Papst Pius II.) aus dem 15. und von Racek Doubravský von Doubravka aus dem 16. Jahrhundert; alle haben die Fassung des Dalimil weiter entwickelt. Auch die von Václav Hájek z Libočan (Wenzeslaus Hajek von Libotschan) in der ersten Hälfte des 16. Jahrhunderts verfasste Version übernimmt und ergänzt im Grunde die Version des Dalimil. Es gibt drei tschechische Libretti mit dem Thema des Mädchenkrieges, und zwar von Julius Zeyer, Karel Pippich und Anežka Schulzová. Das Libretto Śárka von Julius Zeyer ist auf Anregung von Antonín Dvořák wahrscheinlich im Jahre 1880 entstanden, Dvořák hat es jedoch dem Schriftsteller zurückgegeben. Auch bei Bedřich Smetana und Karel Bendl erweckte der Text kein Interesse. Es war der damals als Komponist noch unbekannte Leoš Janáček, der Zeyers Libretto vertont hat - allerdings ohne dessen Wissen und mit wesentlichen Umarbeitung des Textes. So ist es verständlich, dass Zeyer, als ihn Janáček im Nachhinein davon verständigte und ihn um seine Bewilligung bat, sich verletzt fühlte und die Vertonung verbot. Ein weiterer Grund war die Polemik um Smetana zwischen Janáček und dem Redakteur der Zeitschrift Dalibor, Václav Vladimír Zelený. Kein Wunder, dass Zeyer, als er sich bei Zelený über Janáček informierte, keine positive Antwort erhielt. Dies hat seine Entscheidung, dem Komponisten die Verwendung des Librettos nicht zu gestatten (obwohl die Oper bereits komponiert wurde), nur unterstützt. 


\title{
Českým skladatelům přitažlivá i odpudivá Šárka
}

\begin{abstract}
Shrnutí
Téma dívčí války se v české literatuře objevuje poprvé v Kosmově Kronice Čechů. Zde je však líčena jen jako hra mezi jinochy a dívkami. V pozdější české veršované kronice takřečeného Dalimila z počátku 14. století je již pověst vylíčena jako dívčí válka s propracovaným dějem i jmény postav. Další zpracování od kronikáře Přibíka Pulkavy z Radenína ze druhé poloviny 14. století, Aeneáše Sylvia Piccoliminiho (posléze papeže Pia II.) z 15. století a Racka Doubravského z Doubravky ze 16. století vycházela z Dalimilovy verze př́iběhu. Také znění kronikáře Václava Hájka z Libočan z první poloviny 16. století přebírá v podstatě Dalimilovo vyprávění, které je však poněkud rozšiřeno. V českém prostředí v 19. století jsou známa tři libreta s tematikou dívčí války: $\mathrm{z}$ pera Julia Zeyera, Karla Pippicha a Anežky Schulzové. První z libret je Šárka od Julia Zeyera. Libreto vzniklo na popud Antonína Dvořáka patrně v roce 1880. Dvořák však libreto Zeyerovi vrátil. Poté bylo neúspěšně nabídnuto Bedřichu Smetanovi a Karlu Bendlovi. Je pochopitelné, že když o libreto požádal tehdy neznámý skladatel Leoš Janáček, který navíc Zeyerovo libreto značně přepracoval, dotčený básník mu zhudebnění zakázal. Důvodem byly i smetanovské spory Janáčka s V. V. Zeleným, redaktorem časopisu Dalibor. Není divu, že když se Zeyer informoval na Janáčka právě u Zeleného, nedostal žádné kladné vyjádření. To také podpořilo jeho rozhodnutí nepovolit Janáčkovi použití libreta, přesto že opera již byla vypracována.
\end{abstract}

\section{Keywords}

Leoš Janáček; opera Šárka; Julius Zeyer. 